\title{
Eksperimen Pengembangan Produk Fungsional Bernilai Komersial Berbahan Baku Tempurung Kelapa Berusia Muda dengan Teknik Pelunakan
}

\author{
Dewi Pugersari $^{1}$, Achmad Syarief ${ }^{2} \&$ Dwinita Larasati $^{2}$ \\ ${ }^{1}$ Program Studi Magister Desain, Fakultas Seni Rupa dan Desain, Institut Teknologi \\ Bandung, Jalan Ganesa No. 10, Bandung 40132, Indonesia \\ ${ }^{2}$ KK Manusia dan Produk Industri, Fakultas Seni Rupa dan Desain, \\ Institut Teknologi Bandung, Jalan Ganesa No. 10, Bandung 40132, Indonesia \\ Email: girlyact_4@yahoo.com
}

\begin{abstract}
Abstrak. Tempurung, sebagai sisa pengolahan buah kelapa, memiliki karakter yang unik, antara lain kuat, keras, bersifat lengkung, dan motif permukaan yang khas. Potensi dan karakter unik tersebut menyebabkan tempurung kelapa dapat dimanfaatkan sebagai bahan baku kerajinan. Penelitian ini dilakukan untuk mengetahui karakter tempurung kelapa dan pemanfaatannya, serta mencari alternatif teknik pengolahan tempurung. Metode yang digunakan dalam penelitian ini adalah eksperimentasi material dan karakteristik tempurung kelapa sebagai bahan baku kerajinan. Dalam penelitian ini dilakukan berbagai eksperimen, yaitu eksperimen pemanfaatan tempurung berdasarkan teknik-teknik yang telah umum dilakukan, eksperimen pewarnaan permukaan tempurung, eksperimen pelunakan dan pembentukan kembali tempurung dengan senyawa basa, serta eksperimen bentuk mengacu pada karakter unik tempurung yang diperoleh dari hasil penelitian. Berdasarkan evaluasi yang telah dilakukan, diperoleh kesimpulan bahwa pemanfaatan tempurung kelapa sebagai bahan baku kerajinan dengan teknik pelunakan menghasilkan produk yang kurang memperlihatkan karakter visual dan dinilai paling tidak alami dibandingkan teknik lain. Namun di sisi lain, produk yang menggunakan teknik pelunakan pun dipandang sebagai produk yang paling sesuai dengan gaya kekinian (kontemporer) dan memiliki keunikan paling tinggi. Hal-hal tersebut menjadikan produk dengan teknik pelunakan dianggap paling menarik dan memiliki potensi yang besar untuk dikembangkan menjadi berbagai produk kerajinan lainnya.
\end{abstract}

Kata kunci: bahan baku kerajinan; eksperimentasi material; karakter unik; produk kerajinan; teknik pelunakan; tempurung kelapa.

\begin{abstract}
Coconut shell, as coconut processing leftover, comes with unique characteristics, such as its strength, hardness, bending flexibility and also special texture of the surface. Those unique potentials and characteristics enable coconut shell to be used as craft materials. The objectives of this research are to find out the shell processing alternative technique and to know more about young age coconut shell's characteristics. The method used for this research is the material experiments and coconut shell as the craft materials, experiment of coconut shell
\end{abstract}

Received September $3^{\text {rd }}, 2012$, Revised September $26^{\text {th }}, 2013$, Accepted for publication November $29^{\text {th }}, 2013$. Copyright (C) 2013 Published by LPPM ITB, ISSN: 1978-3078, DOI: 10.5614/itbj.vad.2013.5.1.5 
utilization using generally known techniques, surface coloring technique, softening technique, reform technique with the help of base substance and experiment that refer to the unique characteristics of coconut shell. According to the evaluation, it is concluded that coconut shell utilization using softening technique resulted in products that show less visual character and least natural compared to other techniques. Product that came out as the result with softening technique is still considered as the most suitable product which goes along with the contemporary style and owns the greatest unique value. It brings consideration that the softening technique- product has a great potential to be developed as other craft products. In addition, coconut shell used in softening technique is the young age shell which has not been used widely.

Keywords: coconut shell; craft materials; craft products; material experiments; softening technique; unique characteristics.

\section{$1 \quad$ Pendahuluan}

Sebagai negara kepulauan yang berada di daerah tropis dengan kondisi agroklimat yang mendukung, Indonesia termasuk negara penghasil kelapa utama di dunia, nomor dua setelah Filipina. Luas areal tanaman kelapa di Indonesia pada tahun 2000 mencapai 3,76 juta ha dengan total produksi diperkirakan sebanyak 14 milyar butir kelapa per tahun.

Tempurung kelapa (batok) yang pada awalnya dianggap sebagai limbah sisa pemanfaatan buah kelapa [1] kini telah banyak dimanfaatkan sebagai bahan baku dalam industri pembuatan arang aktif atau karbon aktif dan tepung tempurung. Manfaat tempurung kelapa sebenarnya dapat ditingkatkan menjadi beraneka macam produk kerajinan bernilai jual dan dapat dipasarkan mulai dari harga murah hingga harga tinggi. Permintaan atas produk kerajinan tempurung kelapa ini pun semakin bertambah seiring dengan berkembangnya gaya hidup "kembali ke alam". Bentuk produk kerajinan tempurung kelapa yang unik dan klasik serta bahan bakunya yang berasal dari bahan alami, memiliki nilai lebih karena ramah lingkungan, lebih didominasi kerajinan tangan dalam prosesnya, dan bernilai estetika tinggi.

Pengolahan tempurung kelapa sebagai produk kerajinan termasuk ke dalam subsektor industri kerajinan, subsektor industri kreatif yang paling membutuhkan riset dan pengembangan untuk meningkatkan nilai tambahnya [2]. Untuk itu, fokus utama penelitian ini adalah pemanfaatan potensi tempurung dari sisa pengolahan buah kelapa berusia sedang (8-10 bulan) dan buah kelapa berusia muda (6-7 bulan). Pemilihan tempurung kelapa berusia sedang dan muda dikarenakan tempurung kelapa tua (11->12 bulan) telah banyak dimanfaatkan untuk industri arang aktif. 
Berdasarkan hal tersebut, penelitian ini tidak mengikutsertakan tempurung kelapa berusia tua sebagai objek kajian untuk menghindarkan pemakaian sumber material yang sama dengan industri yang telah ada [3]. Material tempurung kelapa berusia muda dan sedang dalam penelitian ini diperoleh dari sisa pemanfaatan buah kelapa dari pedagang es kelapa muda.

Penelitian ini bertujuan untuk mengetahui cara-cara pemanfaatan tempurung kelapa berusia muda (6-7 bulan) dan tempurung kelapa berusia sedang (8-10 bulan) sebagai bahan baku kerajinan, desain yang sesuai dengan karakteristik tempurung kelapa, nilai tambah yang dapat dihasilkan dari pengolahan, dan nilai ekonomi serta sosial budaya dari pemanfaatan tempurung kelapa sisa pengolahan buah kelapa. Pendekatan yang digunakan dalam penelitian ini adalah riset terapan (applied research) terhadap material tempurung kelapa sebagai bahan baku kerajinan. Dari penelitian ini diharapkan dapat memberikan kontribusi bagi produsen kerajinan, dalam usaha pengembangan desain kerajinan berbahan tempurung kelapa menjadi produk yang dapat mempunyai nilai jual yang lebih baik.

\section{Metode}

Penelitian ini menggunakan pendekatan riset terapan (applied research) pada material tempurung kelapa sebagai bahan baku produk. Hasil eksperimen digunakan untuk alternatif pengembangan pemanfaatan tempurung kelapa sebagai bahan baku produk. Proses pengumpulan data dalam penelitian ini dilakukan dengan teknik wawancara, memperoleh material, observasi lapangan, dan studi banding ke tempat-tempat usaha kerajinan tempurung kelapa yang sudah ada di Sumedang, Jawa Barat dan Bantul, Yogyakarta. Data yang diperoleh digunakan sebagai acuan dalam eksperimentasi dan rencana pengembangan pemanfaatan tempurung kelapa.

Terdapat tiga tahapan penelitian yang dilakukan, yaitu tahap pendahuluan, tahap eksperimen, dan tahap evaluasi. Tahap pendahuluan terdiri dari proses berpikir dan pengumpulan data-data, baik data primer maupun data sekunder. Hasil yang didapat pada tahap pendahuluan digunakan sebagai acuan dalam tahap eksperimen yang terdiri dari dua bagian, yaitu eksperimen I dan eksperimen II. Eksperimen I meliputi proses eksperimen karakteristik fisik tempurung kelapa, sedangkan eksperimen II meliputi proses pembuatan produk dengan memanfaatkan tempurung kelapa. Tahap akhir yaitu evaluasi atas proses yang telah dilakukan untuk menghasilkan kesimpulan akhir atas penelitian. 


\section{Hasil dan Pembahasan}

\subsection{Karakteristik Tempurung Kelapa}

Berat dan tebal tempurung sangat ditentukan oleh jenis tanaman kelapa. Berat tempurung sekitar 15-19\% bobot total buah kelapa dengan ketebalan 3-5 mm [3]. Tempurung kelapa termasuk golongan kayu keras [4], secara kimiawi memiliki komposisi kimiawi yang hampir mirip dengan kayu yaitu tersusun dari lignin $36,51 \%$, Selulosa $33,61 \%$, Semiselulosa 29,27 , seperti yang tercantum pada Tabel 1 .

Tabel 1 Kandungan Kimiawi Tempurung Kelapa [4].

\begin{tabular}{cc}
\hline Komponen & Presentase (\%) \\
\hline Cellulose & 33,61, \\
Hemicellulose & 19,27 \\
Lignin & 36,51 \\
\hline
\end{tabular}

Pada Tabel 2 dijelaskan bahwa berdasarkan asal lokasi pohon kelapa ditanam, tempurung kelapa dapat dibedakan menjadi dua, yaitu pohon kelapa yang ditanam di daerah pegunungan dan pohon kelapa yang ditanam di daerah pantai. Perbedaan tempat tumbuh pohon kelapa akan menghasilkan ketebalan dan kekerasan tempurung kelapa yang berbeda.

Tabel 2 Pengaruh Daerah Asal Kelapa Tumbuh (Pegunungan dan Pantai) [5].

\begin{tabular}{|c|c|c|}
\hline $\begin{array}{ll}\text { Parameter } & \\
\text { Asal Tumbuh }\end{array}$ & Pegunungan & Pantai \\
\hline Ketebalan & Tebal & Tipis \\
\hline Kekerasan & Kuat & Mudah retak \\
\hline Pisau Potong Produksi & Relatif Mudah Aus & Relatif Tahan Aus \\
\hline Contoh Daerah & $\begin{array}{l}\text { Kupang, Kalimantan, } \\
\text { Pegunungan Ciamis }\end{array}$ & $\begin{array}{c}\text { Pangandaran, Banjar, pantai } \\
\text { Ciamis, pantai Parangtritis }\end{array}$ \\
\hline Pembentukan Manual & $\begin{array}{l}\text { Sulit, memakan waktu } \\
\text { relatif lama }\end{array}$ & Lebih mudah dibentuk \\
\hline Pemanfaatan & $\begin{array}{c}\text { Dimanfaatkan struktur } \\
\text { utuh }\end{array}$ & $\begin{array}{c}\text { Pemanfaatan dengan } \\
\text { pencampuran material lain }\end{array}$ \\
\hline
\end{tabular}

Pohon kelapa yang hidup di daerah pegunungan memiliki tempurung dengan ketebalan dan kekerasan yang lebih besar dari pada pohon kelapa yang hidup di daerah pantai. Perbedaan ketebalan dan kekerasan tempurung berpengaruh pada cara produksi dan produk yang dihasilkan. Tempurung kelapa dengan ketebalan dan kekerasanan lebih rendah akan bersifat lebih lunak dan lebih mudah untuk diolah dibandingkan tempurung kelapa dengan ketebalan dan kekerasan lebih tinggi. Kekerasan tempurung juga berpengaruh pada umur pakai peralatan 
produksi, di mana umur peralatan produksi pengolah tempurung kelapa yang lebih tebal dan keras memiliki umur yang cenderung lebih pendek.

\subsection{Pemanfaatan Material Tempurung}

Tempurung kelapa merupakan bagian dari buah kelapa yang masih belum banyak dimanfaatkan dibandingkan bagian buah kelapa lainnya, meskipun sebagian kecilnya sudah diolah menjadi tepung kelapa dan arang. Selain dimanfaatkan sebagai bahan baku arang dan tepung tempurung, secara karakteristik visual, tempurung kelapa juga dapat dimanfaatkan sebagai bahan baku kerajinan. Pemanfaatan tempurung kelapa sebagai bahan baku kerajinan dapat dilakukan dengan beberapa teknik yang telah diterapkan oleh pengrajin tempurung (lihat Gambar 1). Berdasarkan hasil wawancara dengan Bpk. Siswanto, Instruktur spesialis tempurung kelapa Balai Besar Kerajinan dan Batik Yogyakarta, Agustus 2010, teknik pembuatan produk tempurung dapat dibedakan menjadi tiga, yaitu teknik potong, teknik ikat/rakit dan teknik laminasi.

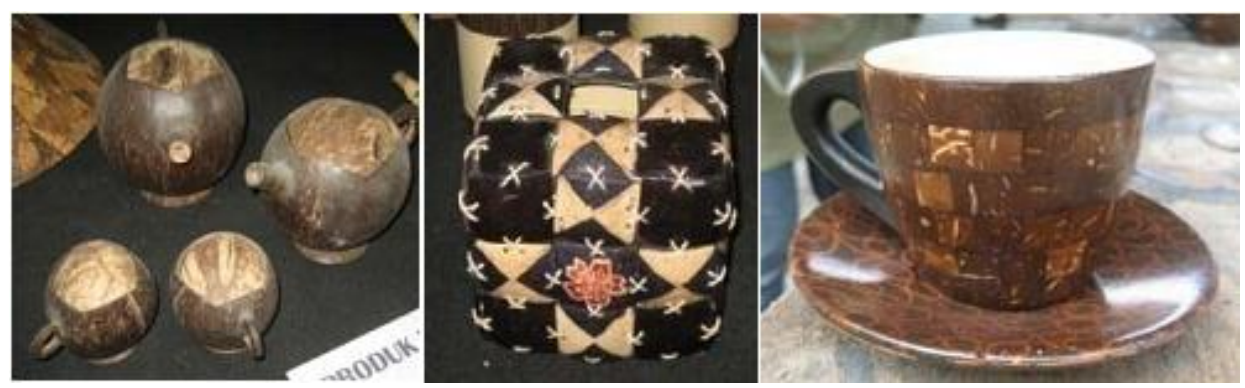

Gambar 1 Pemanfaatan tempurung kelapa dengan teknik potong (a), rakit (b) dan laminasi (c).

\subsection{Eksperimen}

Pemisahan tempurung kelapa dari sabut yang melekat merupakan proses awal pembersihan tempurung untuk dapat diolah. Selanjutnya, setelah dibersihkan dari sabut dan gabus dilakukan pembersihan dan pelunakan dengan menggunakan $\mathrm{NaOH}$ keripik. Zat kimia $\mathrm{NaOH}$ keripik atau natrit hydroxid adalah zat kimia yang banyak digunakan dalam pembersihan serat alam. Eksperimen dengan penambahan $\mathrm{NaOH}$ ini dilakukan dengan jumlah relatif sedikit karena keripik $\mathrm{NaOH}$ dapat menyebabkan iritasi ringan bila terkena kulit manusia. Meskipun dapat menyebabkan iritasi ringan, secara umum $\mathrm{NaOH}$ relatif aman untuk lingkungan, bahkan dapat membunuh bakteri jika dibuang begitu saja ke saluran pembuangan kotoran. $\mathrm{NaOH}$ juga banyak digunakan 
untuk menentralkan limbah industri yang bersifat asam karena $\mathrm{NaOH}$ yang bersifat basa.

Eksperimen pelunakan tempurung kelapa berusia muda dilakukan dengan merendam tempurung bersama $\mathrm{NaOH}$ selama 24 jam sehingga tempurung menjadi lebih lunak. Pada proses ini, setelah tempurung kelapa lunak maka tempurung dapat di-press untuk mengurangi sifat lengkung permukaan tempurung (Gambar 2). Namun, tempurung lunak pun tidak bersifat terlalu elastis sehingga pelurusan harus dilakukan perlahan-lahan untuk menghindari patah atau retakan yang tidak diinginkan.

Jika proses pelunakan ini dilakukan terhadap tempurung kelapa yang masih berbentuk bulat, maka hasilnya tidak dapat benar-benar datar tanpa retakan, hal ini dikarenakan permukaan tempurung yang luas yang berarti juga semakin besar kelengkungannya. Selain berfungsi untuk melunakkan tempurung, perendaman tempurung kelapa ini juga digunakan untuk mengurangi lapisan lilin pada permukaan tempurung yang dapat menghambat penyerapan zat warna.
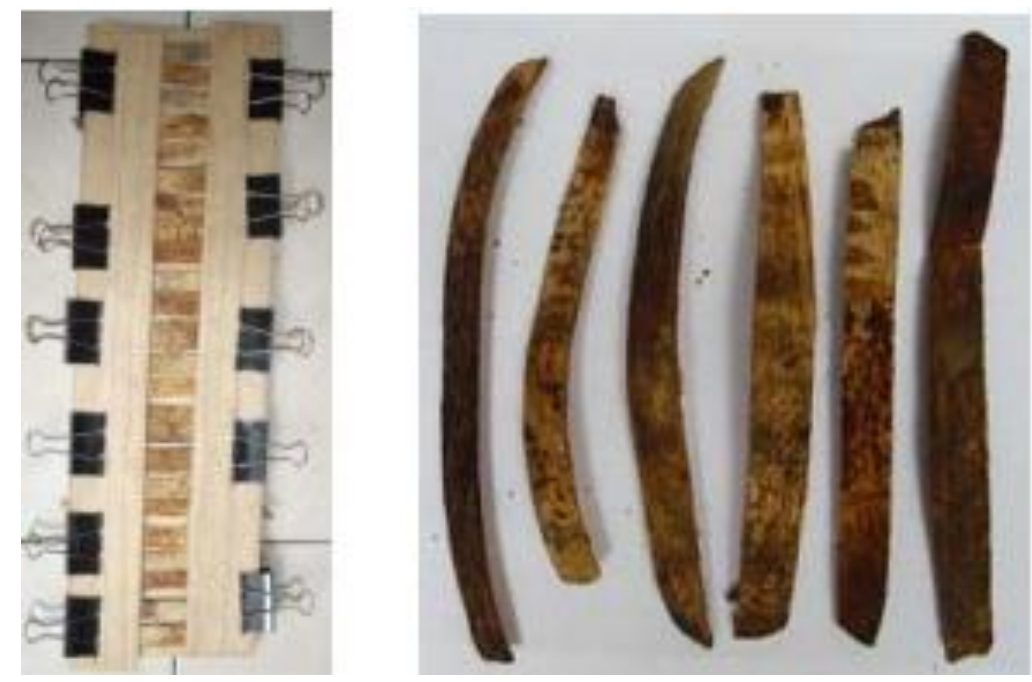

Gambar 2 Proses press/pelurusan tempurung kelapa.

Gambar 3 merupakan hasil eksperimen pembentukan yang dilakukan dengan menusukkan tempurung lunak menggunakan bilah bambu untuk mendapatkan tempurung kelapa yang lebih melengkung. Usaha pembentukan tempurung kelapa dalam eksperimen tersebut tidak cukup efektif karena tempurung kelapa yang dihasilkan setelah kering mengalami pengerutan sehingga bentuk yang dihasilkan tidak beraturan. 


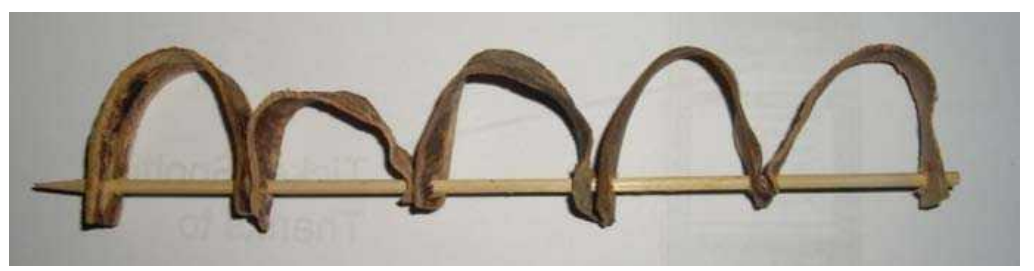

Gambar 3 Eksperimen pembentukan tempurung kelapa dengan bantuan bilah bambu.

Gambar 4 merupakan hasil ekperimen pembentukan yang dilakukan dengan menggunakan cetakan dan alat jepit. Tempurung kelapa berusia muda yang telah melalui proses perendaman $\mathrm{NaOH}$ dan menjadi lebih lunak dibentuk mengikuti cetakan, tempurung kelapa harus benar-benar menempel pada cetakan sehingga pada saat kering bentuk tempurung kelapa akan sesuai dengan bentuk cetakan. Dalam eksperimen ini juga dilakukan penyambungan tempurung kelapa untuk menghasilkan bentuk yang panjang, namun usaha ini tidak berhasil karena sambungan antar tempurung kelapa terlepas atau patah pada saat kering kembali (Gambar 5).

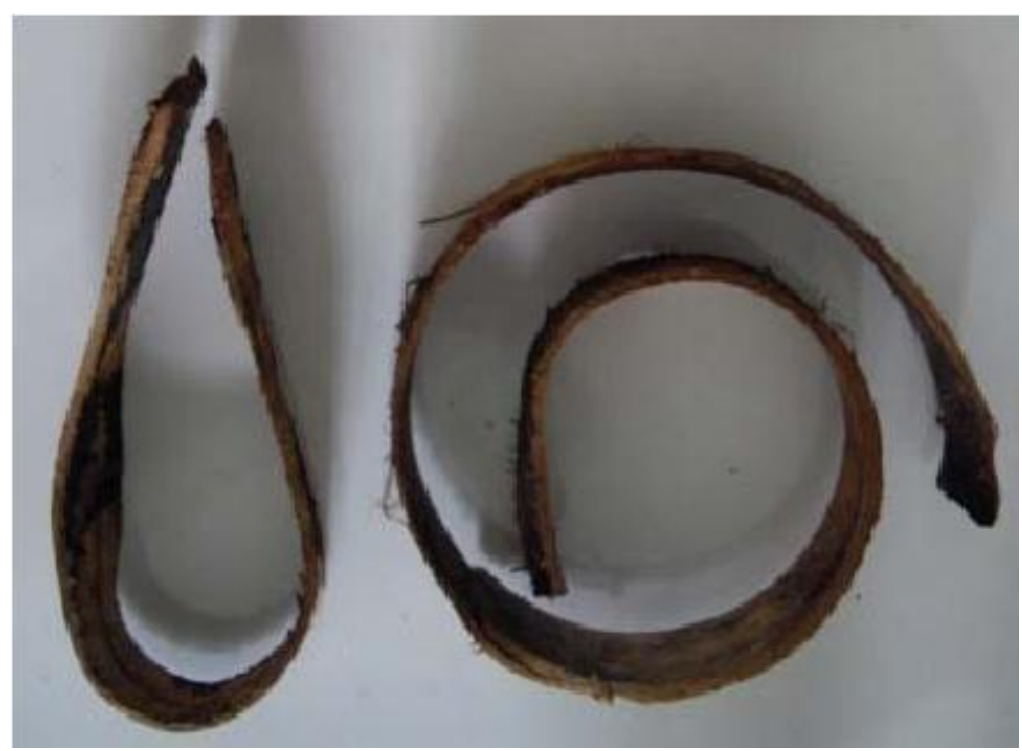

Gambar 4 Pembentukan tempurung lunak dan hasil dengan penjepitan pada plat cetak. 


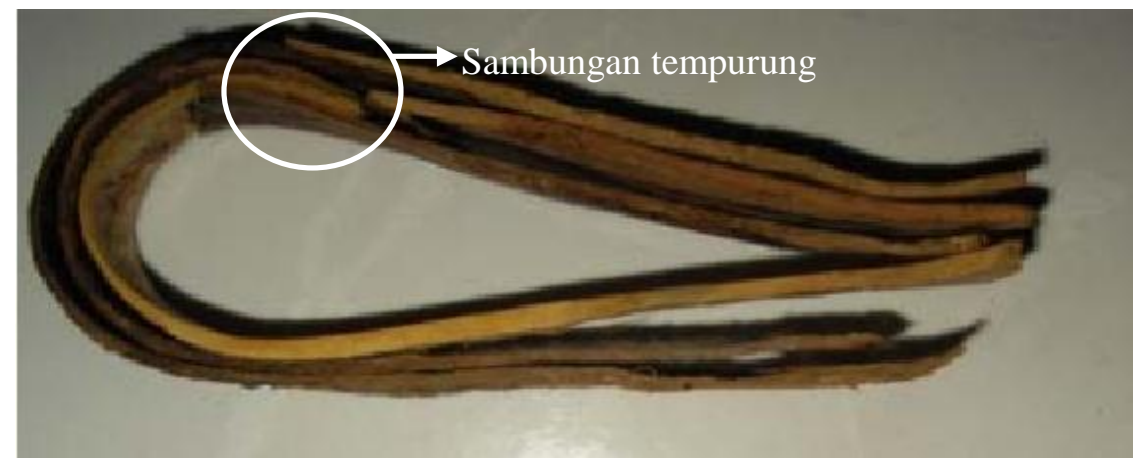

Gambar 5 Hasil pembentukan tempurung lunak dengan penyambungan.

Selanjutnya dilakukan proses pembentukan dengan mengikat tempurung kelapa yang sudah dilunakkan pada cetakan berbentuk silinder (Gambar 6). Dari hasil eksperimen, tempurung kelapa dapat dibentuk melengkung hingga diameter terkecil $\pm 2,5 \mathrm{~cm}$ tanpa proses lanjutan (perapihan). Penggunaan bahan pengikat sebagai pengganti penjepit plat cetak mampu mempersingkat waktu yang dibutuhkan untuk proses pembentukan secara signifikan.
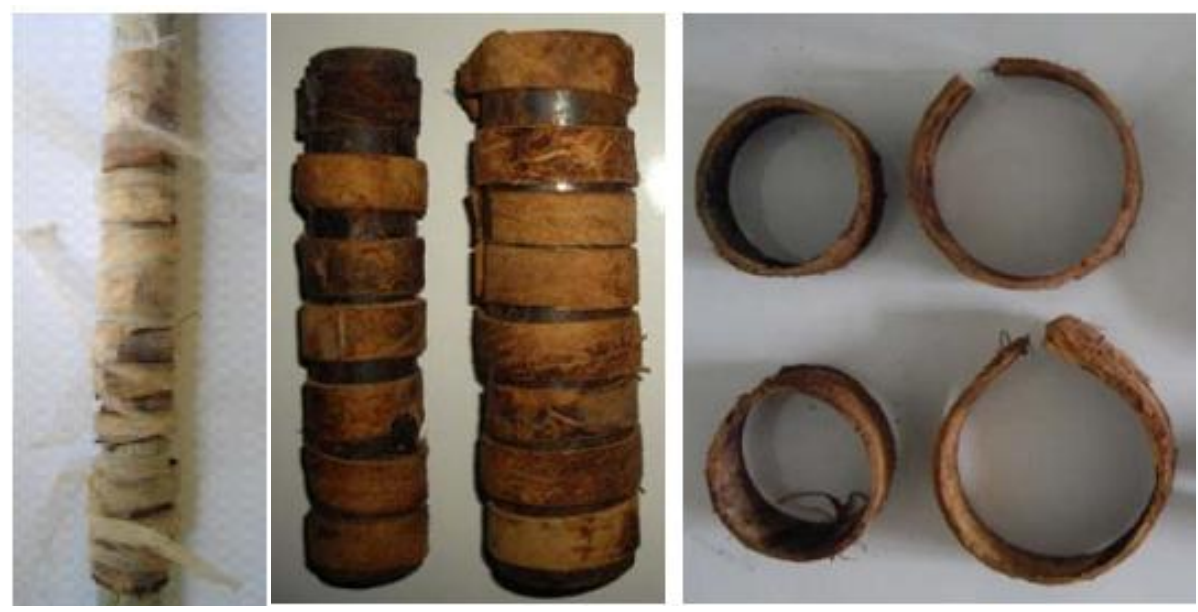

Gambar 6 Pembentukan tempurung kelapa dengan bahan pengikatan pada plat cetak.

Setelah tempurung kelapa mengering, tempurung akan mengalami sedikit penyusutan atau pengerutan dan relative lebih rapuh. Untuk menambah kekuatan tempurung kelapa, maka tempurung disusun berlapis (Gambar 7). 


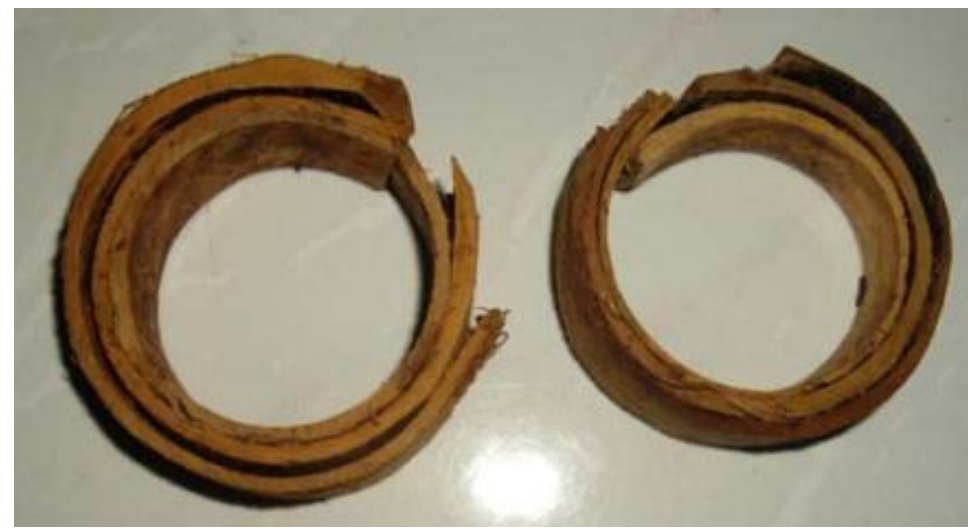

Gambar 7 Usaha menambah kekuatan tempurung kelapa.

\subsection{Eksperimen Bentuk}

Eksperimen ini dimaksudkan untuk mendapatkan bentuk tiga dimensi yang diawali dengan pembentukan modul yang akan menunjang sebuah rangkaian. Gambar 8 merupakan proses pembentukan dan perapihan modul yang dilakukan dengan pemanasan dan pemotongan tempurung.
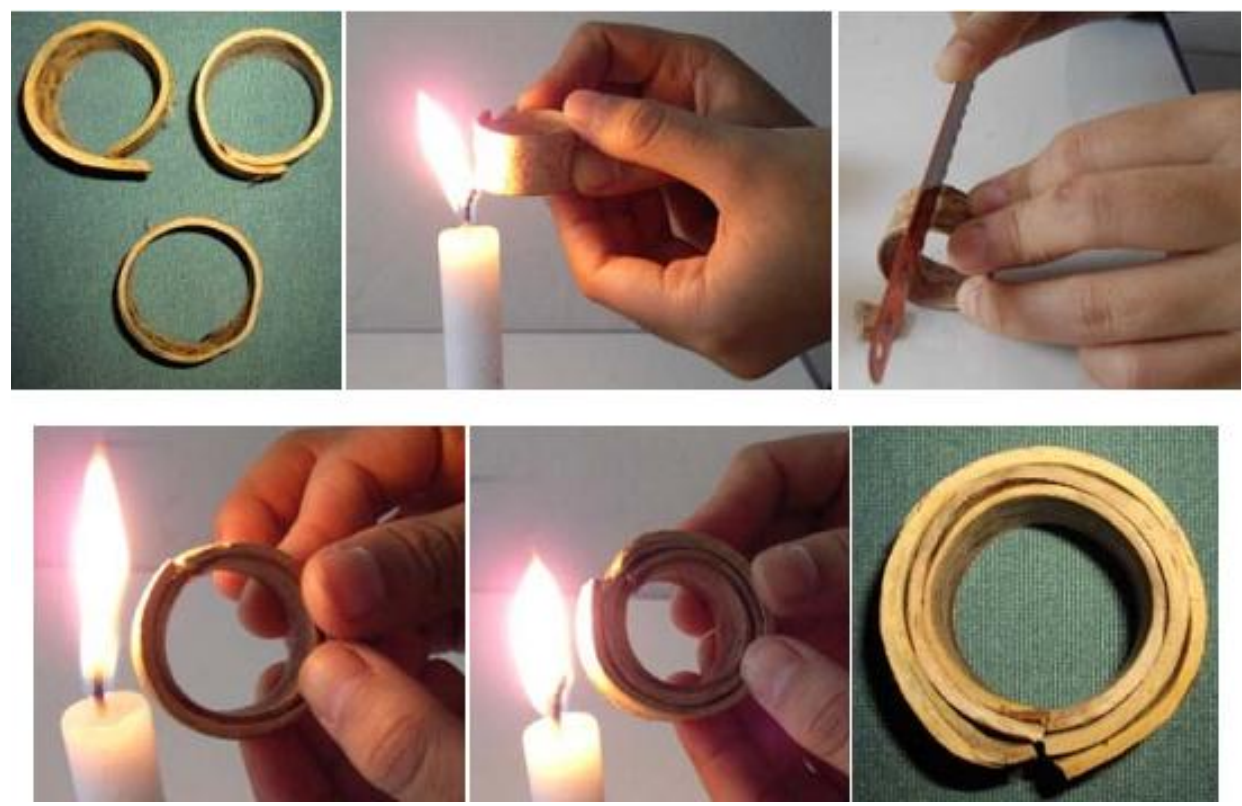

Gambar 8 Proses pembentukan dan perapihan modul. 
Pemanasan tempurung dilakukan sebagai usaha membentuk tempurung, alat yang digunakan yaitu plat (pencetak/pembentuk) dan api (pemanas). Pengaruh panas akan membuat tempurung sedikit melunak karena adanya pemuaian sehingga bentuk tempurung dapat lebih mudah dirapihkan. Bentuk lingkaran tertutup merupakan bentuk yang paling sesuai untuk tempurung kelapa karena tempurung kelapa memiliki sifat lengkung yang sulit dibentuk menjadi bentuk yang memiliki sudut.
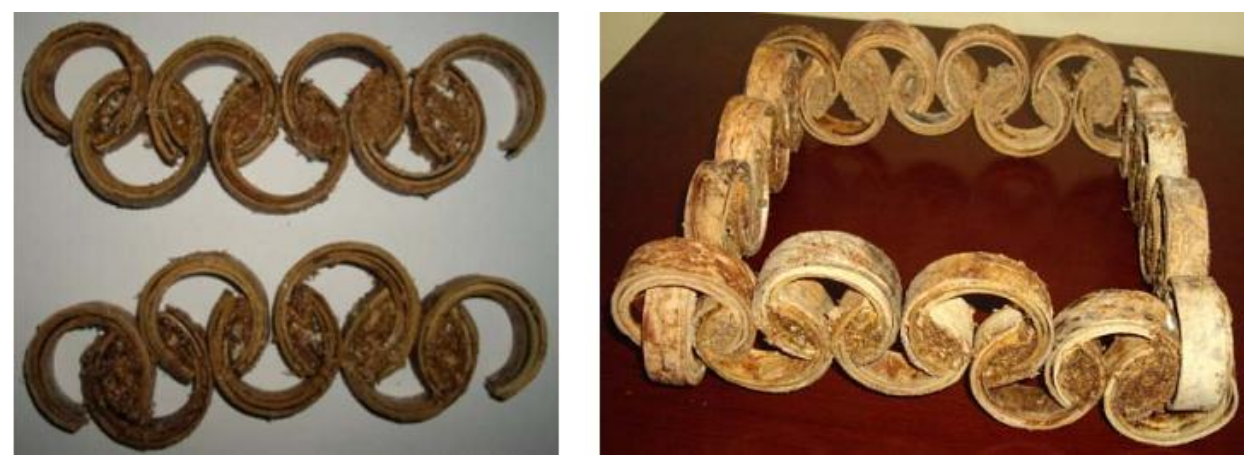

Gambar 9 Tempurung kelapa muda (6-7 bulan) lunak dibentuk menjadi bentuk berdimensi tiga.

Eksperimen bentuk dilakukan pada tempurung kelapa muda (6-7 bulan) dengan memanfaatkan perekat kayu dan serbuk gergaji/tempurung sebagai pengisi (filler). Tempurung kelapa muda yang telah dilunakkan dan dibentuk, disatukan dengan perekat dan filler (Gambar 9).

Analisis terhadap kemampuan material utama, material pendukung dan bahan pendukung produk dilakukan untuk melihat kemampuan daur ulang atau kemampuan seluruh komponen pembentuk produk untuk diuraikan oleh alam. Berikut analisa komponen pembentuk produk:

\section{Tempurung kelapa}

Tempurung kelapa merupakan material biodegradable yaitu material yang dapat diuraikan secara alami oleh mikroorganisme di dalam tanah. Tempurung kelapa, baik tempurung kelapa tanpa proses lanjutan maupun tempurung kelapa hasil perendaman $\mathrm{NaOH}$, dapat membusuk dan terurai dengan sendirinya oleh alam. Sisa tempurung kelapa hasil perendaman $\mathrm{NaOH}$ yang tidak terpakai dapat dijadikan pupuk dalam keadaan basah/lunak, sedangkan tempurung kelapa hasil perendaman $\mathrm{NaOH}$ kering/keras dapat ditimbun atau dibuang begitu saja dialam karena kemampuannya untuk terurai dengan sendirinya. 


\section{Bahan perendam}

Proses pembentukan produk dalam eksperimen ini menggunakan bahan perendam berupa bahan kimia Natrium Hidroksida $(\mathrm{NaOH})$. Bahan perendam ini digunakan sebagai bahan pembantu melunakkan material utama. $\mathrm{NaOH}$ bersifat basa dan biasa dimanfaatkan untuk mengontrol jumlah bakteri dalam air limbah. Limbah $\mathrm{NaOH}$ dapat dibuang langsung ke saluran pembuangan air umum, namun lebih baik lagi jika dilakukan penetralan dengan menambahkan zat asam. Sifat basa pada $\mathrm{NaOH}$ dapat menyebabkan iritasi ringan jika bersentuhan langsung dengan kulit, karena itu pelindung seperti sarung tangan karet perlu digunakan dalam proses perendaman dan pengolahannya.

\section{Bahan perekat}

Lem kayu putih $\mathrm{PVaC}$ digunakan dalam penyatuan modul untuk membentuk produk. PVaC atau Polyvinyl acetate merupakan suatu senyawa polimer yang bersifat elastis yang ditemukan oleh Dr. Flitz K. dari Jerman. Zat ini banyak digunakan sebagai campuran utama bahan perekat pada industri perkayuan. Selain $\mathrm{PVaC}$, zat lain yang terkandung dalam bahan perekat yang digunakan yaitu Polyvynil Alkohol (PVA), Dextrin, Resol $65 \%$, dan air. Bahan perekat ini merupakan bahan yang mudah larut dalam air (water based) dan tidak mengandung senyawa sintesis kimia berbahan dasar minyak bumi (solvent based), di mana senyawa kimia solvent based merupakan karsinogen atau zat yang dapat memicu kanker dan juga mudah terbakar. PVaC sebagai bahan yang mudah larut dalam air tidak mencemari lingkungan, tidak merusak lingkungan, tidak berbau tajam, dan lebih mudah terurai sehingga dapat digolongkan sebagai produk ramah lingkungan.

\section{Filler}

Bahan pengisi atau filler yang digunakan yaitu campuran perekat dan serbuk kayu atau serbuk tempurung. Bahan-bahan tersebut merupakan material biodegradable yaitu material yang dapat diuraikan secara alami oleh mikroorganisme di dalam tanah.

\section{Finishing}

Penyempurnaan produk (finishing) dilakukan untuk membuat permukaan tempurung tidak kusam dan lebih mengkilat. Proses terdiri dari penghalusan permukaan produk dan penggosokan untuk mendapatkan permukaan yang lebih mengkilat. Terdapat dua pilihan bahan pendukung yang dapat digunakan untuk mengkilatkan permukaan, produk yaitu daun pisang kering dan Langsol (batu hijau). 


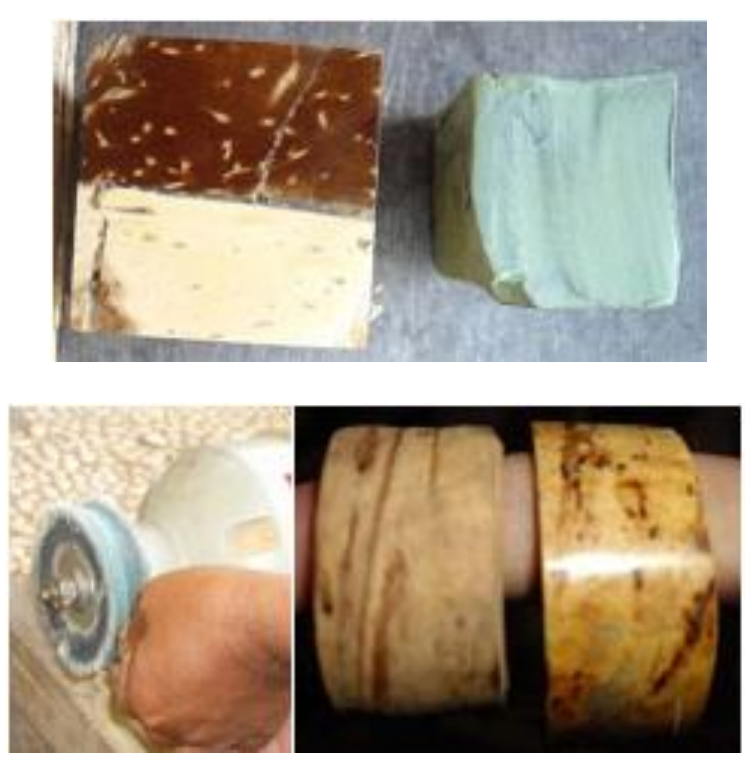

Gambar 10 Finishing menggunakan Langsol.

Pengkilatan dengan cara menggosokkan daun pisang kering pada permukaan produk dilakukan secara manual sehingga memerlukan waktu cenderung panjang. Sedangkan pengkilatan menggunakan Langsol membutuhkan waktu yang relatif singkat dan memberikan hasil kilat yang signifikan (Gambar 10).

\subsection{Analisis Eksperimen, Perancangan Dan Realisasi}

Berdasarkan karakteristik tempurung hasil eksperimen, sifat lengkung tempurung yang dapat ditambah atau dikurangi dan kemampuan tempurung untuk dibentuk/dicetak dengan tetap mempertahankan sifat kuatnya merupakan karakteristik tempurung yang belum banyak diolah namun memiliki potensi nilai tambah yang lebih tinggi. Karakteristik tersebut perlu dioptimalkan dalam pengembangan produk kerajinan tempurung kelapa sebagai produk hasil industri kreatif, yang lebih unik dibandingkan produk-produk yang sudah ada.

Karakteristik tempurung dan eksperimen yang telah dilakukan menjadi bahan pertimbangan dalam perancangan produk berbahan baku tempurung kelapa. Berdasarkan klasifikasi produk industri Locarno Agreement, produk berbahan baku tempurung kelapa hasil eksperimen penelitian ini, dapat digolongkan menjadi empat katagori yaitu Travel Goods, Furnishing, Household Goods dan Articles of Adornment (Tabel 3). 
Tabel 3 Pertimbangan yang harus dimiliki dalam perancangan produk tempurung kelapa.

\begin{tabular}{|c|c|c|}
\hline Kelas & Contoh Produk & $\begin{array}{c}\text { Pertimbangan yang } \\
\text { harus dimiliki }\end{array}$ \\
\hline $\begin{array}{l}\text { Travel Goods } \\
\text { (Barang-barang } \\
\text { bawaan, kotak, } \\
\text { dan milik Pribadi, } \\
\text { (dan lain-lainnya ) }\end{array}$ & $\begin{array}{l}\text { Peti, kopor, tas, tas jinjing (tangan), } \\
\text { gantungan kunci, tasyang didesain } \\
\text { khusus sesuai isi, kantong dan hal- } \\
\text { hal sejenis. }\end{array}$ & $\begin{array}{l}\text { Kekuatan menahan } \\
\text { beban }\end{array}$ \\
\hline Furnishing & $\begin{array}{l}\text { Tempat tidur, tempat duduk (kursi), } \\
\text { meja, perabot (alat-alat) } \\
\text { penyimpanan, cermin dan bingkai, } \\
\text { perabot lain dan bagian-bagian } \\
\text { perabot. }\end{array}$ & $\begin{array}{l}\text { Kekuatan menahan } \\
\text { beban } \\
\text { - Outdoor: } \\
\text { 1. Kekuatan terhadap } \\
\text { sinar matahari/ } \\
\text { cuaca. } \\
\text { 2. Tahan terhadap air. }\end{array}$ \\
\hline Household Goods & $\begin{array}{l}\text { Perlengkapan dan peralatan } \\
\text { memasak, dan wadah (kontainer), } \\
\text { perlengkapan dan alat-alat untuk } \\
\text { menyajikan makanan atau } \\
\text { minuman, porselen, peralatan dari } \\
\text { kaca, mangkok dan barang-barang } \\
\text { lain yang mempunyai sifat yang } \\
\text { sama. }\end{array}$ & $\begin{array}{l}\text { - Kekuatan menahan } \\
\text { beban } \\
\text { - Tahan terhadap air }\end{array}$ \\
\hline $\begin{array}{l}\text { Articles of } \\
\text { Adornment }\end{array}$ & Perhiasan, sabuk. & $\begin{array}{l}\text { - Ringan untuk dipakai. } \\
\text { - Tidak menimbulkan } \\
\text { iritasi kulit secara } \\
\text { langsung. }\end{array}$ \\
\hline
\end{tabular}

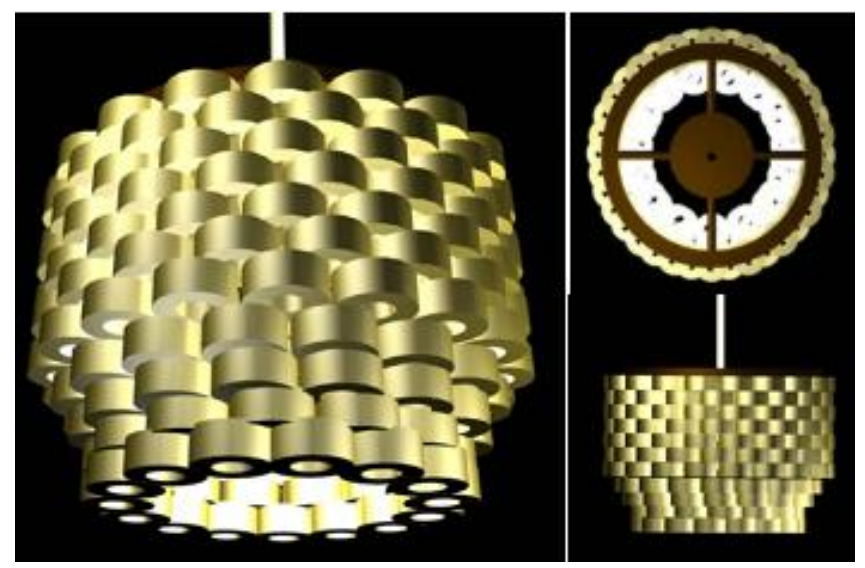

Gambar 11 Gagasan desain. 
Hampir keseluruhan produk fungsional dapat dibentuk dari material tempurung kelapa dengan berbagai pertimbangan dan kompromi untuk penyempurnaan bentuk akhir produk. Pemetaan peluang produk dibuat untuk memberikan informasi berbagai peluang produk berbeda yang dapat diaplikasikan dari bahan baku tempurung kelapa. Dengan mempertimbangkan waktu pengerjaan dan SDM dalam realisasi proyek akhir ini, maka lampu dipilih sebagai contoh realisasi proyek akhir penelitian (Gambar 11).
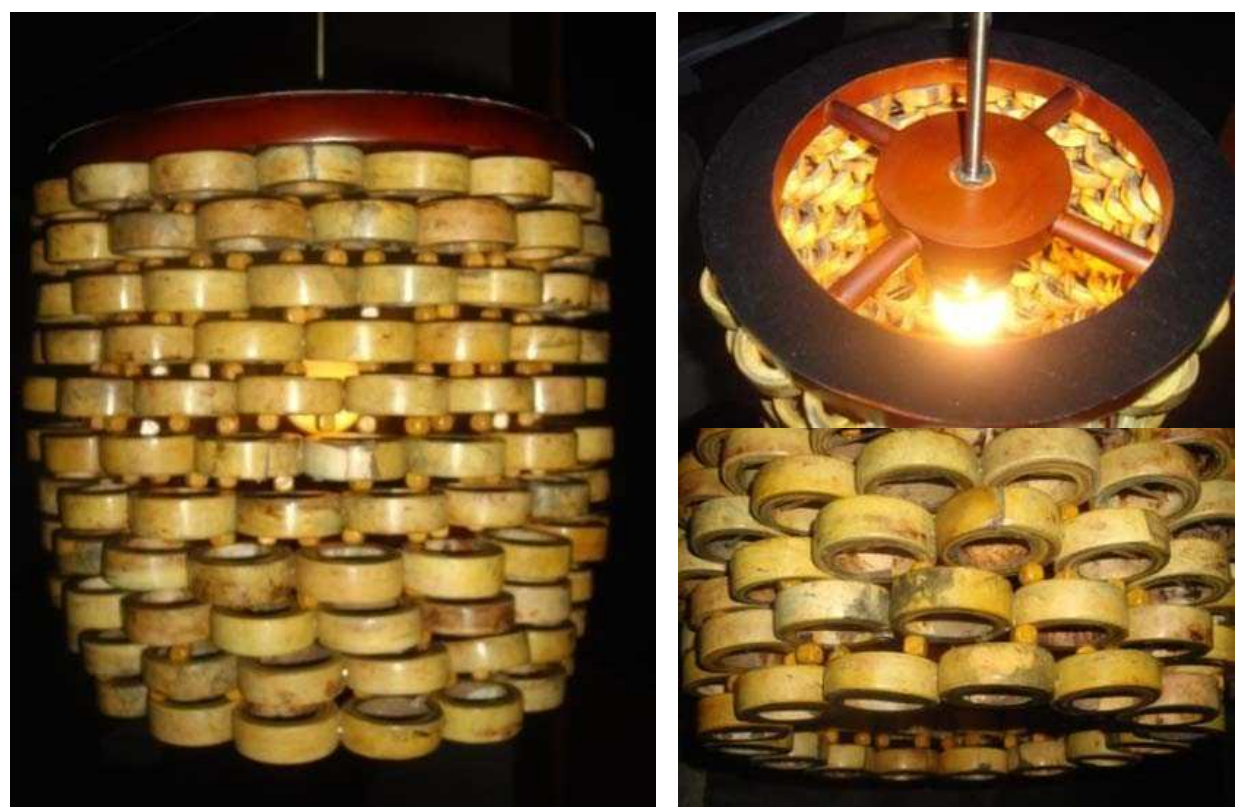

Gambar 12 Realisasi produk akhir.

Realisasi produk merupakan tahap yang menentukan dapat atau tidaknya rangkaian proses perancangan diterapkan menjadi sebuah produk jadi. Tahap ini terdiri dari beberapa rangkaian proses saling berkaitan yang menentukan hasil akhir.

Produk akhir pada penelitian ini merupakan contoh pemanfaatan tempurung kelapa sebagai bahan baku produk kerajinan dengan teknik pelunakan (Gambar 12). Produk akhir dibuat untuk melakukan evaluasi hasil penerapan teknik pelunakan, sebagai hasil penelitian, dibandingkan dengan teknik lain dalam pemanfaatan tempurung kelapa.

\subsection{Evaluasi}

Evaluasi dilakukan dengan melakukan perbandingan antara produk kerajinan tempurung kelapa menggunakan teknik pelunakan, hasil eksperimen, dengan 
produk kerajinan tempurung kelapa menggunakan teknik lain, yaitu teknik potong, ikat, dan laminasi.

Untuk itu, dilakukan penyebaran kuisioner kepada beberapa sampel responden terpilih yang dianggap mewakili pengrajin, pakar, dan konsumen umum. Kuisioner ini digunakan untuk mengetahui penilaian objektif responden terhadap produk kerajinan berbahan baku tempurung kelapa dengan berbagai teknik, selanjutnya digunakan sebagai bahan evaluasi. Empat gambar visual sebagai sampel produk berbahan baku tempurung kelapa dengan menggunakan teknik potong, ikat/rakit, laminasi dan pelunakan diperlihatkan kepada responden. Penilaian menggunakan garis sebagai skala ukur (variabel numerik/kuantitatif) dengan nilai terendah 0 hingga nilai tertinggi 10 . Responden diminta memberikan garis vertikal pada garis skala ukur sebagai penilainya untuk setiap sampel produk. Penilaian dalam kuisioner meliputi sembilan aspek, yaitu:

1. Kemudahan untuk dikenali sebagai tempurung kelapa secara visual

2. Kealamian produk

3. Keunikan produk

4. Ketahanan produk

5. Kesederhanaan produk

6. Kekinian produk

7. Ketertarikan terhadap produk

8. Potensi pengembangan produk

9. Nilai produk

Berdasarkan perbandingan yang diperoleh dari kuisioner (Gambar 13), diketahui bahwa karakter visual tempurung kurang nyata terlihat jika dibandingkan dengan produk yang menggunakan teknik lain. Selain itu, produk yang menggunakan teknik pelunakan dinilai paling tidak alami dan berdaya tahan paling rendah dibandingkan teknik lain. Sebaliknya, produk tempurung kelapa dengan teknik pelunakan justru dianggap paling tidak sederhana dibandingkan dengan produk yang menggunakan teknik lain.

Namun di sisi lain, produk yang menggunakan teknik pelunakan pun dipandang sebagai produk yang paling sesuai dengan gaya kekinian (kontemporer) dan memiliki keunikan paling tinggi. Hal-hal tersebut menjadikan produk dengan teknik pelunakan dianggap paling menarik dan memiliki nilai yang tinggi, sedikit di bawah produk dengan teknik laminasi. 


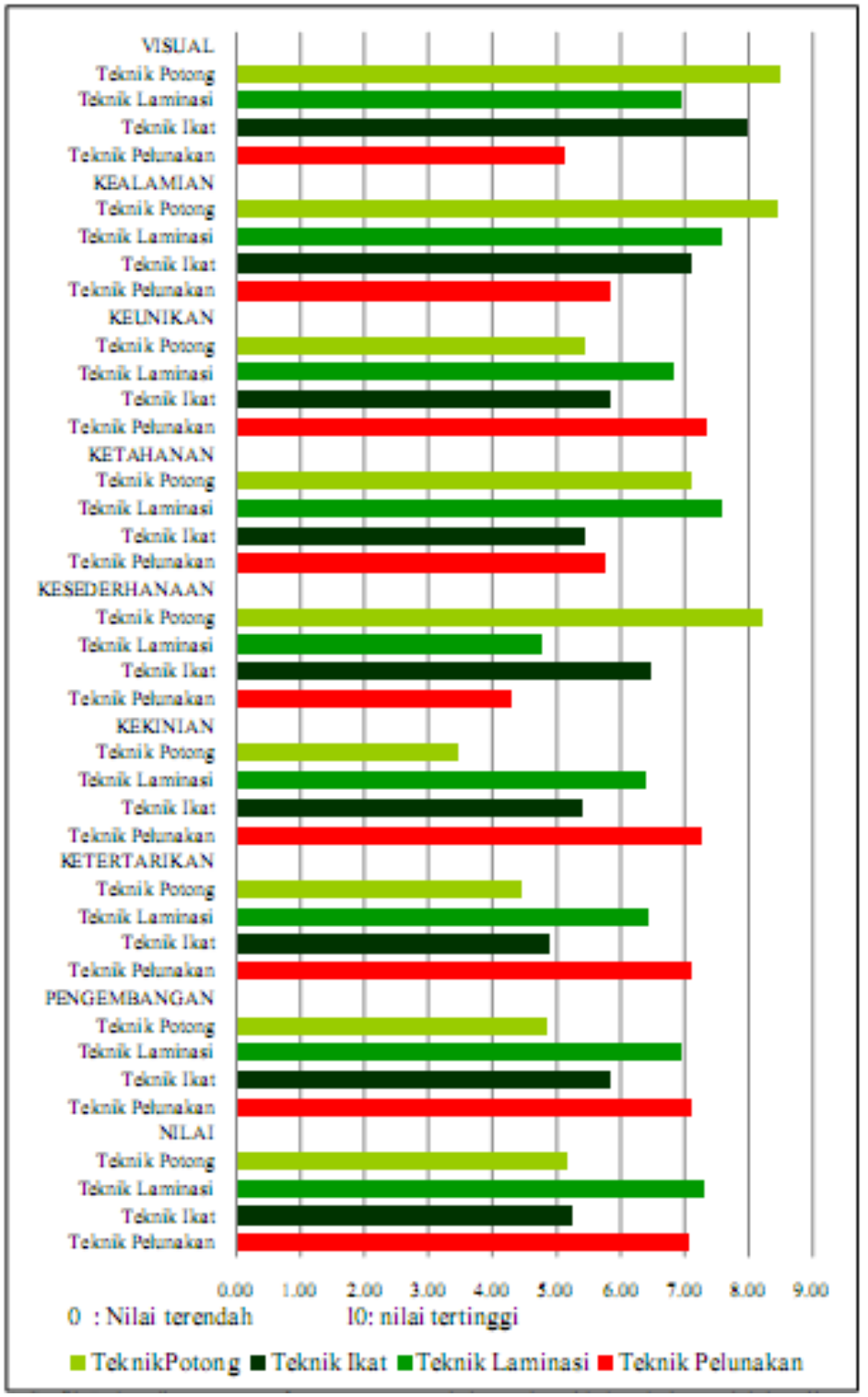

Gambar 13 Grafik Perbandingan pemanfaatan tempurung kelapa sebagai bahan baku produk kerajinan dengan berbagai teknik.

Keunikan dan nilai produk yang tinggi tersebut, menyebabkan produk berbahan baku tempurung kelapa dengan teknik pelunakan pun dinilai memiliki potensi yang paling besar untuk terus dikembangkan menjadi berbagai produk kerajinan lainnya. 


\section{$4 \quad$ Kesimpulan}

Berdasarkan hasil pengumpulan data mengenai potensi tempurung kelapa dan berbagai macam cara pemanfaatannya, serta eksperimen material yang telah dilakukan, diketahui bahwa material tempurung kelapa memiliki potensi yang sangat besar dan memiliki beberapa karakter material yang unik, yaitu kuat, lengkung, motif permukaan yang khas, dan tahan air. Potensi dan karakter unik tersebut menyebabkan tempurung kelapa dapat dimanfaatkan sebagai bahan baku kerajinan, yang antara lain telah dikembangkan dengan menggunakan teknik potong, teknik ikat/rakit, dan teknik laminasi.

Dari eksperimen ini juga diketahui satu karakter unik lain dari tempurung kelapa, yaitu dapat dilunakkan dan dibentuk kembali. Dari karakter tersebut dihasilkan alternatif baru pemanfaatan tempurung kelapa, yaitu dengan teknik pelunakan dan pembentukan.

Dari hasil penelitian, juga diperoleh kesimpulan bahwa pemanfaatan tempurung kelapa sebagai bahan baku kerajinan dengan teknik pelunakan menghasilkan produk yang kurang memperlihatkan karakter visual tempurung jika dibandingkan dengan produk yang menggunakan teknik lain. Selain itu, produk yang menggunakan teknik pelunakan dinilai paling tidak alami dan berdaya tahan paling rendah dibandingkan teknik lain. Sebaliknya, produk tempurung kelapa dengan teknik pelunakan justru dianggap paling tidak sederhana dibandingkan dengan produk yang menggunakan teknik lain.

Namun di sisi lain, produk yang menggunakan teknik pelunakan pun dipandang sebagai produk yang paling sesuai dengan gaya kekinian (kontemporer) dan memiliki keunikan paling tinggi. Hal-hal tersebut menjadikan produk dengan teknik pelunakan dianggap paling menarik dan memiliki nilai yang tinggi, sedikit di bawah produk dengan teknik laminasi.

Keunikan dan nilai produk yang tinggi tersebut, menyebabkan produk berbahan baku tempurung kelapa dengan teknik pelunakan pun dinilai memiliki potensi yang paling besar untuk terus dikembangkan menjadi berbagai produk kerajinan lainnya.

Ditambah lagi, pada teknik pelunakan, bahan baku tempurung kelapa yang digunakan adalah tempurung kelapa berusia muda, yang belum banyak dimanfaatkan, baik oleh industri arang, tepung, maupun kerajinan dengan teknik lain. Dengan pendekatan yang tepat, produk kerajinan tempurung kelapa yang menggunakan teknik pelunakan memiliki potensi sebagai produk premium yang sangat unik. 


\section{Ucapan Terima Kasih}

Penelitian ini dapat diselesaikan berkat dukungan dari berbagai pihak, karena itu penulis mengucapkan terimakasih kepada: Bapak Siswanto dari Balai Besar Kerajinan dan Batik, Yogyakarta, Bapak Wayan dari Pandikar Studio, Bapak Alan dan Jerry Art Studio.

\section{Referensi}

[1] Rusvirman, M., Hernandi, S., Daslin, N. \& Silviea, N.A. 2010. Penelitian Pendahuluan Pemanfaatan Limbah Pedagang Air Kelapa Muda Bandung (makalah Jurusan Kimia Fakultas Matematikaa dan Ilmu Pengetahuan Alam), Cimahi: Universitas Jenderal Achmad Yani.

[2] Pangestu, M.E. 2008. Pengembangan Industri Kreatif Menuju Visi Ekonomi Kreatif Indonesia 2025, Jakarta: Departemen Perdagangan RI.

[3] Mahmud, Z. \& Ferry, Y. 2005. Prospek Pengolahan Hasil Samping Buah Kelapa, Jurnal Pusat Penelitian dan Pengembangan Perkebunan, 4(2), Bogor: Penelitian dan Pengembangan Perkebunan.

[4] Prananta, J. 2007. Pemanfaatan Sabut dan Tempurung Kelapa Serta Cangkang Sawit untuk pembuatan Asap Cair Sebagai Pengawet Makanan Alami (Laporan Penelitian Making Applied Technology Work For Marginal People Direktur Eksekutif Jingki Institute), Lhokseumawe: Alumnus Universitas Malikussaleh.

[5] Wawancara dengan Bpk. Siswanto, Instruktur Spesialis Kelapa Balai Besar Kerajinan dan Batik Yogyakarta (Agustus, 2010). 